\title{
Erratum to chemoprotective effect of atorvastatin against benzo(a)pyrene-induced lung cancer via the inhibition of oxidative stress and inflammatory parameters
}

\section{Editorial Office}

Annals of Translational Medicine

Correspondence to: Editorial Office. Annals of Translational Medicine. Email: editor@atmjournal.org.

Submitted Jun 22, 2021. Accepted for publication Jun 25, 2021.

doi: $10.21037 /$ atm-2021-23

View this article at: https://dx.doi.org/10.21037/atm-2021-23

Erratum to: Ann Transl Med 2021;9:355

In the article entitled "Chemoprotective effect of atorvastatin against benzo(a)pyrene-induced lung cancer via the inhibition of oxidative stress and inflammatory parameters" (1), funding information was incorrect in the full text of HTML version. Therefore, the information "Funding: none" in the HTML version should be corrected as "Funding: Shaanxi Key Research and Development Program: 2018SF-267.", which is the same as that in the published PDF version.

Open Access Statement: This is an Open Access article distributed in accordance with the Creative Commons AttributionNonCommercial-NoDerivs 4.0 International License (CC BY-NC-ND 4.0), which permits the non-commercial replication and distribution of the article with the strict proviso that no changes or edits are made and the original work is properly cited (including links to both the formal publication through the relevant DOI and the license). See: https://creativecommons.org/ licenses/by-nc-nd/4.0/.

\section{References}

1. Du X, Li D, Wang G, et al. Chemoprotective effect of atorvastatin against benzo(a)pyrene-induced lung cancer via the inhibition of oxidative stress and inflammatory parameters. Ann Transl Med 2021;9:355.

Cite this article as: Editorial Office. Erratum to chemoprotective effect of atorvastatin against benzo(a)pyreneinduced lung cancer via the inhibition of oxidative stress and inflammatory parameters. Ann Transl Med 2021;9(14):1214. doi: 10.21037/atm-2021-23 